\title{
Start-up of halophilic nitrogen removal via nitrite from hypersaline wastewater by estuarine sediments in sequencing batch reactor
}

\author{
Y. W. Cui · J. R. Ding $\cdot$ S. Y. Ji $\cdot$ Y. Z. Peng
}

Received: 6 May 2012/Revised: 24 December 2012/Accepted: 1 January 2013/Published online: 28 February 2013

(C) Islamic Azad University (IAU) 2013

\begin{abstract}
Nitrogen removal from hypersaline wastewater was successfully started up by inoculating estuarine sediments for 140 days. Efficient ammonia and total nitrogen removal was sustained under specific ammonia loading of $0.016-0.139 \mathrm{~kg} \mathrm{~N} /[\mathrm{kg}$ VSS day] in a sequencing batch reactor. Stable nitrite accumulation was observed during nitrification. The specific ammonia consumption rate was higher than the value of freshwater activated sludge and saltacclimated freshwater activated sludge. With methanol as carbon source, specific nitrite reduction rate of halophilic denitrifiers was much less than the freshwater counterpart. Halophilic activated sludge was characterized as good settling and flocculation prosperity with small floc size and netlike sludge structure. The abundance of ammonia-oxidizing bacteria outnumbered ammonia-oxidizing archaeas in both estuarine sediments and the activated sludge. Nitrifier population was dominated by the halophilic members of genus Nitrosomonas. This study demonstrated the application of mixed halophilic consortia for efficient nitrogen removal, overcoming the limits and difficulties of applying freshwater bacteria for saline wastewater treatment.
\end{abstract}

Keywords Halophilic sludge - Nitrite accumulation . Nitrifier population $\cdot$ Salinity $\cdot$ Short-cut nitrification

\section{Introduction}

Saline and hypersaline wastewater (above $3 \%$ salinity) accounts for about $5 \%$ worldwide effluent, generated by

Y. W. Cui $(\bowtie) \cdot$ J. R. Ding · S. Y. Ji · Y. Z. Peng College of Environmental and Energy Engineering, Beijing University of Technology, 100 Pingleyuan, Chaoyang District, Beijing 100124, China

e-mail: cyw@bjut.edu.cn extensive industries or practices such as fish aquaculture, food factory, tannery, chemicals, pharmaceuticals, and flushing toilets by seawater (Cui et al. 2009; Lefebvre 2006). The wastewater contains high concentration of carbonaceous and nitrogenous contaminants as well as high amount of inorganic salts. Removal of carbonaceous and nitrogenous contaminants from saline wastewater before discharging is essential to avoid oxygen depletion and eutrophication in receiving waters. In fact, environmental pollution and ecology impairment caused by discharge of saline wastewater have never been prevented. The lack of efficient and economical treatment technology applicable for saline wastewater mainly resulted in this situation. Treatment requirement of saline wastewater was intensified with the annual increase of wastewater generation sources and amount (Lefebvre 2006).

It attracts increasing interests to develop saline wastewater treatment technology and has witnessed some important progress recently. Metabolism-oriented engineering approach, acclimating freshwater microorganisms to saline environment, was the most often reported approach, which has been proved feasible to obtain satisfying removal of carbonaceous and nitrogenous pollutants at relatively low salinity (Bassin et al. 2011; Panswad and Anan 1999; Uygur 2006). However, further application of this approach for hypersaline wastewater treatment is limited by difficulties that (1) salt-adapted biological system cannot perform stable and effective pollutant removal from saline wastewater containing over $3 \%$ salinity, especially for removal of nitrogenous matters (Panswad and Anan 1999), that (2) low sedimentation efficiencies induced by high buoyancy in high-salinity environment interfered with effective solid-liquid separation (Panswad and Anan 1999; Uygur 2006), and that (3) serious salt inhibition reduced bacterial activity, resulting in inactivity 
or even death (Chen et al. 2003). Therefore, utilizing salt acclimation of freshwater bacteria seemed impossible to treat hypersaline wastewater. To overcome these obstacles, Woolard and Irvine (1995) used pure halophilic microorganisms to obtain an average phenol removal of over $99.5 \%$ at $15 \%$ salinity. Then, several studies have also demonstrated that utilization of halotolerant or halophilic bacteria could be the suitable solution for hypersaline wastewater treatment (Abou-Elela et al. 2010; Peyton et al. 2001). It should be pointed out that pure halophilic or halotolerant bacteria were employed in these studies. However, mixed biomass rather than pure culture is required in practical wastewater treatment engineering. Most recently, a successful attempt to obtain mixed halophilic biomass was done by enriching them from seawater and marine sediment samples (Sudarno et al. 2010). It opened a door for biological treatment of hypersaline wastewater by mixed halophilic biomass, marching a big step toward the practical treatment engineering of hypersaline wastewater.

Because of the limited research, there are some unresolved problems to prevent the further application of halophiles in engineering design and operation. Firstly, the foremost is where we can obtain halophiles as inocula for system start-up. Available information has indicated that halophiles thrive extensively in natural ecological niches such as solar saltern, sea, saline lake, estuary, saline soil and other salty fields (Zhuang et al. 2010). Till now, only limited natural sources of halophile, for example soil sample (Gross et al. 2003), saline wastewater (Gharsallah et al. 2002), seawater and marine sediment (Sudarno et al. 2010), have been chosen as inocula to obtain halophilic or halotolerant biomass. Due to the diversity of halophiles, functional population in the halophilic system would differ from natural sources of halophiles, showing different ability of pollution removal as well. To this meaning, extensive attempts to obtain halophilic biomass from different sources are important to finally establish one better solution to system start-up. Secondly, the key of efficient biological treatment mainly relies on sufficient biomass. The difficulty of operating a halophilic biological system is how to obtain sufficient biomass in relatively short time. This is more difficult for nitrifiers due to their very slow growth rates (Peng and Zhu 2006). Oriented to engineering, fast-growth and easy enrichment would offer appeal to shorten start-up time and to reduce the cost. Finally, given that the biomass inoculated from natural habitat can adapt successfully to process conditions, treatment performance and kinetics are required for further engineering design and operation.

Therefore, the objectives of this research are (1) to start up nitrogen removal system for hypersaline wastewater by inoculating estuarine sediments, which is the first attempt to our best knowledge; (2) to investigate performance and kinetics of halophilic treatment for hypersaline wastewater; and (3) to explain some process phenomena by insight into the microbial population structure.

\section{Materials and methods}

Estuarine sediments, elutriation procedure and wastewater quality

Estuarine sediments as natural sources of halophilic nitrifiers were collected from the estuary of Tang River in Qinhuangdao city of Hebei Province. Sampling site $\left(39.924^{\circ} \mathrm{N}, 119.574^{\circ} \mathrm{E}\right)$ is about $500 \mathrm{~m}$ away from the Bo Sea. Estuarine sediments were collected $2-3 \mathrm{~cm}$ below the sediment interface to reduce sand content in sediment samples, about $0.2-0.5 \mathrm{~m}$ below water surface. Sediment samples $(5 \mathrm{~L})$ were filled into sterilized plastic bottles with stopper and stored in an ice box during transportation to the laboratory. The physical-chemical characteristics of sampled sediments were determined. The $\mathrm{pH}$ of estuarine sediments was 7.2. Estuarine sediments consisted of $24 \%$ organic matter and $76 \%$ inorganic sand. The mean particle size of sediments was $36.33 \mu \mathrm{m}$.

The elutriation of collected sediments was carried out three times before experiment. Firstly, 5-L collected sediments were put into a 10-L vessel equipped with a mechanical mixer and a blow-down pipe at the bottom of the vessel. 5-L tap water was added into the vessel, then 5 -min mix by the mechanical mixer was followed. Followed by 1-min settlement, 3-L mixed liquor was decanted by the blow-down pipe. In the second elutriation of collected sediments, 3-L tap water was filled into the vessel again. Then, all the procedures were strictly repeated as the first time except that the settlement time was lengthened to 2 min. In the last elutriation, the settlement time was lengthened to $3 \mathrm{~min}$ and other procedures were maintained as the second time. After the last sand washout, the sediment mixture was further settled. The final sediments $(3 \mathrm{~L}$, volatile suspended solid (VSS) $0.345 \mathrm{~g} / \mathrm{L}$ ) were inoculated in one sequencing batch reactor (SBR).

Saline wastewater as raw wastewater for experiments was prepared by adding salts into the real sewage. The real sewage was delivered daily by the sewer line from residential zone. Commercial salts with $98 \%$ sodium chloride content were added into the sewage to form saline wastewater containing about $30 \mathrm{~g} / \mathrm{L}$ salinity. The water quality of the sampling site and the saline wastewater applied for experiments was characterized. The characteristics of the estuarine water varied over ranges of $\mathrm{pH} 7.5-7.8$, chemical oxygen demand (COD) $20-40 \mathrm{mg} / \mathrm{L}, \mathrm{NH}_{4}{ }^{+}-\mathrm{N} 5-13 \mathrm{mg} / \mathrm{L}$, $\mathrm{NO}_{3}{ }^{-}-\mathrm{N}$ 0.5-1.0 mg/L. $\mathrm{NO}_{2}{ }^{-}-\mathrm{N}$ was not found in the estuarine water. The salinity in estuarine water fluctuates in 
the range of $0.5-2.6 \%$ depending on the ebb tides and flood tides. The water of sampling site was polluted obviously by the perennial input of waste produced by some fishers inhabiting this area, which can be judged by the high ammonia concentration. The characteristics of the saline wastewater used for experiments varied over ranges of $\mathrm{pH}$ 7.2-7.7, COD 190-325 mg/L, $\mathrm{NH}_{4}{ }^{+}-\mathrm{N} 32-85 \mathrm{mg} / \mathrm{L}$, $\mathrm{NO}_{3}{ }^{-}-\mathrm{N} 0.05-0.84 \mathrm{mg} / \mathrm{L}, \mathrm{NO}_{2}{ }^{-}-\mathrm{N} 0.05-0.30 \mathrm{mg} / \mathrm{L}$, total nitrogen (TN) $37-92 \mathrm{mg} / \mathrm{L}$, and salinity $28-32 \mathrm{~g} / \mathrm{L}$.

\section{Experimental setup and operational strategy}

Experiments were carried out in the SBR with a working volume of $8 \mathrm{~L}$, equipped with temperature control system, mechanical stirrer and air diffusers. The temperature was fixed at $24 \pm 1{ }^{\circ} \mathrm{C}$ by means of temperature control system during the whole experiment. Compressed air with constant air supplying rate $(200 \mathrm{~L} / \mathrm{h})$ was supplied via diffusers at the bottom of the reactor. The $\mathrm{pH}$ was not adjusted and controlled during all treatment cycles. Mixing inside the reactor was performed by a mechanical stirrer. Each complete SBR cycle consisted of 5-min feeding, 6-h aeration, 4-h anoxic mixing, 40-min settling and 15-min decanting. At the end of aeration period, 5-mL methanol, which provided sufficient carbon source for anoxic denitrification, was added into the SBR. During the decanting period, 5-L supernatant liquor was discharged, which resulted in a volume exchange ratio of 0.625 . All the processes of SBR cycle were controlled by the timers.

The periodic fluctuation of $\mathrm{NH}_{4}{ }^{+}-\mathrm{N}$ concentration in raw wastewater led to different nitrogen loading rates (NLR) at the condition of constant hydraulic retention time (HRT) of $16 \mathrm{~h}$. During experiments, we still found high sand content in the activated sludge. In order to further eliminate sand from activated sludge, sand washout from activated sludge was carried out at day 59 , following the same procedure as described in part of elutriation procedure. Thus, different mean influent ammonia concentration and VSS resulted in differentiated specific ammonia loadings in the 140-day operation. Depending on mean specific ammonia loadings, the whole experimental period was divided into four operation phases (from phase A to D). The process parameters, including mean NLR and mean specific ammonia loading at every operation phase, are summarized in Table 1.

Analytical methods

Dissolved oxygen (DO) concentration, temperature and $\mathrm{pH}$ were determined using Online WTW Multi 340i Meter (WTW Company, Germany). Salinity was measured by salinity meter (GMK510, Korea). $\mathrm{NH}_{4}{ }^{+}-\mathrm{N}$, $\mathrm{NO}_{2}{ }^{-}-\mathrm{N}, \mathrm{NO}_{3}{ }^{-}-\mathrm{N}, \mathrm{TN}$, mixed liquor suspended solids
(MLSS) and VSS were measured according to standard methods (APHA 1995). To avoid salt interferences, the standard COD test was measured according to the alkaline permanganate methods (Cui et al. 2009). The floc or particle size in activated sludge and in inoculated sediment was measured by the Winner 2116 (Winner instrument, China), which enabled the measurement in the range of $0.1-2,000 \mu \mathrm{m}$. TN and total organic carbon (TOC) were measured by the analyzer (Vario TOC, Elementar, Germany).

Scanning electron microscopy (SEM) observation

The morphology of the estuarine sediment, the activated sludge before sand washout (at day 58) and the activated sludge after sand washout (at day 120), were examined with high resolution SEM (FEI QUANTA 200, FEI Company, USA). Samples were fixed with $2.5 \%$ glutaraldehyde in a $0.1 \mathrm{M}$ phosphate buffer. Subsequently, the samples were washed and dehydrated in a series of ethanol solution $(50,70,80,90$, and $100 \%)$. The dewatered samples were dried by the freeze-drying method and further coated with gold spraying for SEM observation.

FISH, DNA extraction and real-time quantitative PCR analysis

Nitrifier community in estuarine sediments and the activated sludge were visualized by fluorescence in situ hybridization (FISH) with 16S rRNA-targeted oligonucleotide probes according to the method described by Amann et al. (1990). The specific oligonucleotide probes used in this study are: $\mathrm{EUB}_{\text {mix }}$ for the detection of the domain bacteria (Amann et al. 1990), NSO190 for the detection of betaproteobacterial ammonia-oxidizing bacteria (AOB) (Mobarry et al. 1996), NEU for most of the halophilic and halotolerant Nitrosomonas sp. (Wagner et al. 1995), NSMR76 for Nitrosomonas marina-like AOB (Burrell et al. 2001), NIT3 for Nitrobacter sp. (Wagner et al. 1995), and NTSPA685 for the Nitrospira moscoviensis, Nitrospira marina, aquarium clone 710-9 (Hovanec et al. 1998). The images of FISH samples were captured using an Olympus-BX 61 fluorescence microscope. The abundance percentage of interested bacteria was determined as the mean percentage by the different combinations of double hybridizations, carried out by Image-pro plus 6.01 Software.

DNA were extracted from 0.07 to $0.2 \mathrm{~g}$ of freeze-drying activated sludge or estuarine sediments using a Fast Soil DNA isolation kit (Qbiogene, Carlsbad, CA) according to the manufacturer's protocol. The extracted DNA were eluted with $75 \mu \mathrm{L}$ of DES (DNase/pyrogen-free water) and stored at $-20{ }^{\circ} \mathrm{C}$ until use. 
Table 1 Parameters in operation phases

\begin{tabular}{llllllll}
\hline & $\begin{array}{l}\text { Operation } \\
\text { cycles }\end{array}$ & $\begin{array}{l}\text { Sand } \\
\text { washout }\end{array}$ & $\begin{array}{l}\text { VSS } \\
(\mathrm{mg} / \mathrm{L})\end{array}$ & $\begin{array}{l}\text { Mean NLR } \\
{\left[\mathrm{kg} \mathrm{N} /\left(\mathrm{m}^{3} \text { day }\right)\right]}\end{array}$ & $\begin{array}{l}\text { Mean specific } \\
\text { ammonia loading } \\
[\mathrm{kg} \text { N/(kg VSS day })]\end{array}$ & $\begin{array}{l}\text { HRT } \\
(\mathrm{h})\end{array}$ & $\begin{array}{l}\text { SRT } \\
\text { (day) }\end{array}$ \\
\hline Phase A & $1-29$ & No & 642 & 0.090 & 0.139 & 16 & $\begin{array}{l}\text { Not } \\
\text { control }\end{array}$ \\
Phase B & $30-59$ & No & 4,200 & 0.067 & 0.016 & 16 & 20 \\
Phase C & $60-99$ & Yes & 3,000 & 0.076 & 0.025 & 16 & 16 \\
Phase D & $100-140$ & Yes & 3,100 & 0.067 & 0.022 & 16 & 16 \\
\hline
\end{tabular}

Primer pairs amoA-1F/amoA-2R and Arch-amoAF/ Arch-amoAR were used for real-time PCR of bacterial and archaeal amoA genes, respectively, following the real-time PCR protocols (Wang et al. 2011). Tenfold serial dilutions of a known copy number of the plasmid DNA were subjected to real-time PCR in triplicate to generate an external standard curve. The results with efficiency and correlation coefficient above $95 \%$ and 0.98 were employed.

\section{Calculation}

After feeding, samples were taken from the SBR every hour to measure $\mathrm{NH}_{4}{ }^{+}-\mathrm{N}, \mathrm{NO}_{2}{ }^{-}-\mathrm{N}$ and $\mathrm{NO}_{3}{ }^{-}-\mathrm{N}$, allowing determination of some main process kinetics. These process kinetics were calculated by the following equations.

Nitrite accumulation rate (NAR) refers to Eq. (1).

$\mathrm{NAR}=\frac{S_{\mathrm{NO}_{2}^{-}-\mathrm{N}}}{S_{\mathrm{NO}_{2}^{-}-\mathrm{N}}+S_{\mathrm{NO}_{3}^{-}-\mathrm{N}}} \times 100 \%$

where $S(\mathrm{mg} / \mathrm{L})$ is the concentration of $\mathrm{NO}_{2}{ }^{-}-\mathrm{N}$ or $\mathrm{NO}_{3}{ }^{-}$ $\mathrm{N}$.

Specific ammonia consumption rate $\left(q_{\mathrm{NH}_{4}^{+}-\mathrm{N}}\right)[\mathrm{mg} \mathrm{N} /$ (g VSS L)] and specific nitrite consumption rate $\left(q_{\mathrm{NO}_{2}^{-}-\mathrm{N}}\right)$ [mg N/(g VSS L)] were calculated by Eqs. (2) and (3), respectively.

$q_{\mathrm{NH}_{4}^{+}-\mathrm{N}}=-\frac{1}{X} \frac{\mathrm{d} S_{\mathrm{NH}_{4}^{+}-\mathrm{N}}}{\mathrm{d} t}$

$q_{\mathrm{NO}_{2}^{-}-\mathrm{N}}=-\frac{1}{X} \frac{\mathrm{d} S_{\mathrm{NO}_{2}^{-}-\mathrm{N}}}{\mathrm{d} t}$

where $X(\mathrm{~g} / \mathrm{L})$ represents biomass concentration, measured as VSS.

Since short-cut nitrification occurred in this study, specific growth rate of AOB $\left(\mu_{\mathrm{A}}\right)\left(\right.$ day $\left.^{-1}\right)$ can be estimated by Eq. (4) (Gao et al. 2010). In this equation, $Y_{\mathrm{A}}$ (g VSS/ $\mathrm{g}$ COD) is the yield coefficient of AOB. Because yield coefficient of halophilic AOB is still missing, $Y_{\mathrm{A}}$ is fixed as 1 , which is equal to the empirical value provided by ASM3. The constant $\mathrm{A}$ is obtained by fitting the results by the Eq. (5) (Gao et al. 2010). The principle of least-squares method was used to fit the cycle data and to obtain $\mathrm{A}$ and $\mathrm{C}$
$\left(R^{2}>98 \%\right)$. The simulation was performed with Matlab 6.5 .

$\mu_{\mathrm{A}} \approx \frac{\mathrm{A} Y_{\mathrm{A}}}{M X}$

$t=-\frac{1}{\mathrm{~A}}\left(S_{\mathrm{NH}_{4}^{+}-\mathrm{N}}+K_{\mathrm{A}} \ln S_{\mathrm{NH}_{4}^{+}-\mathrm{N}}\right)+\mathrm{C}$

where $M$ is the distribution ratio of $\mathrm{AOB}$ in all bacteria, which is obtained by FISH. A and $\mathrm{C}$ are the constants. $K_{\mathrm{A}}$ is substrate affinity. A, C and $K_{\mathrm{A}}$ were all obtained by simulation.

\section{Results and discussion}

Characterization of treatment performance

Treatment performance of 140-day continuous operation is depicted in Fig. 1. After inoculating the estuarine sediments, saline wastewater containing mean ammonia concentration of $60 \mathrm{mg} \mathrm{N} / \mathrm{L}$ was treated in SBR during phase A. The ammonia oxidization occurred at the tenth day, with a 9-day lag time (Fig. 1a). The lag time of halophilic AOB in this study is similar to the result worked by Sudarno et al. (2010) who found that ammonia oxidization by enrichments from seawater or seawater/mud mixtures occurred after a 10-day lag time. However, a previous research reported that nitrification initiated after a long lag time of 14-18 days when animal manure, polluted soil, effluents of fishery industries, and marine sediments were used as inocula (Antileo et al. 2002). The lag time is necessary for microorganisms to synthesize enzyme system and adapt the new conditions. The different observations are possibly owing to the nutrient requirements of inocula and the microbial population size in inocula. Many halophiles have complex nutrient requirements for amino acids and vitamins due to their incomplete biosynthetic pathways (Woolard and Irvine 1995). In this study, sewage applied to experiments contained rich nutrients enough to satisfy the requirement for halophiles, which could shorten the lag time. Another reason of the different lag time is possibly related to functional bacterial population size in inocula. 

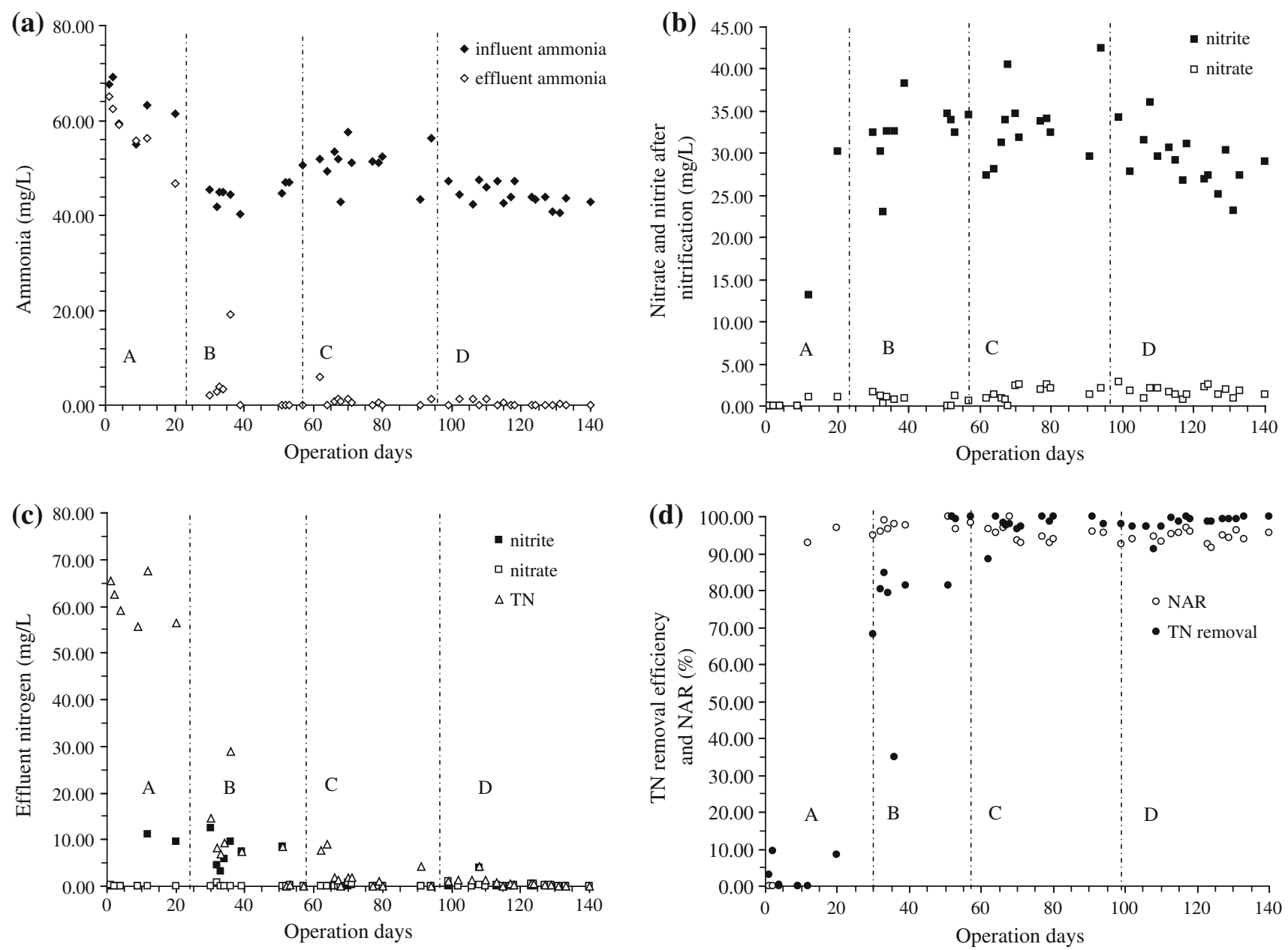

Fig. 1 Time course profiles of nitrogen removal in the SBR treating saline wastewater: a ammonia in the influent and the effluent, $\mathbf{b}$ nitrate and nitrite after nitrification, $\mathbf{c}$ nitrite, nitrate and TN in the effluent and $\mathbf{d}$ TN removal efficiency and NAR

The AOB abundance in its natural habitat is influenced by the local contamination situation. High ammonia concentration in estuarine water $\left(\mathrm{NH}_{4}{ }^{+}-\mathrm{N}\right.$ range of $\left.5-13 \mathrm{mg} / \mathrm{L}\right)$ indicated that pollution took place in the sampling site, implying possibility of high AOB abundance in estuarine sediments. The deduction was further supported by Antileo et al. (2002), who found higher abundance of AOB in the marine sediments than that in freshwater, polluted soil and animal manure. Short lag phase means the fast start-up of treatment system, providing significant cost advantage.

During the 140-day operation, four phases were distinguished concerning the mean specific ammonia loadings. Complete ammonia oxidization occurred at the end of phase A with a very high mean specific ammonia loading of $0.139 \mathrm{~kg} \mathrm{~N} /(\mathrm{kg}$ VSS day) induced by the high influent ammonia concentration and the low biomass concentration. Stable ammonia removal was kept in succeeding phases B, $\mathrm{C}$ and $\mathrm{D}$ with mean specific ammonia loading below
$0.025 \mathrm{~kg} \mathrm{~N} /(\mathrm{kg}$ VSS day). The results indicate that the nitrification of halophilic system can be carried out in a wide range of specific ammonia loading. Different from nitrification, denitrification with $5 \% \mathrm{TN}$ removal was found on the 20th day, lagging 10 days after ammonia oxidization occurred. Therefore, at least 30 days were needed for enriching halophilic denitrifiers from estuarine sediments. The results imply that the enrichment of denitrifiers is more difficult than nitrifiers. The TN removal was highly dependent on the specific nitrate or nitrite loadings. Throughout the experiments, nitrite was the dominant end-product of nitrification (Fig. 1b), which resulted in distinct mean specific nitrite loadings from 0.011 to $0.025 \mathrm{~kg} \mathrm{~N} /(\mathrm{kg}$ VSS day) in the four operation phases. $100 \% \mathrm{TN}$ removal was found on day 51 in phase $\mathrm{B}$, when specific nitrite loading decreased to 0.015 from $0.025 \mathrm{~kg} \mathrm{~N} /(\mathrm{kg} \mathrm{VSS}$ day) of phase A. In the following days, $100 \%$ ammonia and TN removal efficiency was 
sustained regardless of fluctuation of specific ammonia and nitrite loadings, which indicated the successful start-up of the halophilic system. Since the microorganisms living in marine sediments usually have a very small niche for survival (Zhang et al. 2011), it is difficult to enrich marine bacteria when changing the original natural living conditions into the bioreactor operating conditions. The successful start-up of this system explores new possibilities to develop the mixed halophiles for hypersaline wastewater treatment in the practical engineering field.

A noted phenomenon was that the end-product of nitrification is nitrite, with over $97 \%$ NAR obtained during the whole operation (Fig. 1d). By inoculating seawater and sediment samples into fixed-bed reactors, Sudarno et al. (2010) also found nitrite accumulation when some operating conditions were out of control, for example, malfunction of the $\mathrm{pH}$ titrator, detachment of biofilms and increased ammonia loading. It is not surprising that unstable process operation can result in intermediary nitrite accumulation because nitrite oxidizing bacteria (NOB) are more sensitive to disturbance of process conditions than AOB. However, in our study stable air supply provided sufficient $\mathrm{DO}$ for nitrification and $\mathrm{pH}$ was not controlled during all the SBR operation cycles. A typical SBR cycle is depicted in Fig. 2, showing the DO and $\mathrm{pH}$ evolution with nitrogen dynamics. The results indicate that evolution of $\mathrm{DO}$ and $\mathrm{pH}$ is consistent with the normal regulation during nitrification and denitrification (Gao et al. 2010). Furthermore, incomplete nitrification to nitrite is independent of influent ammonia loadings and operation time. Therefore, the results imply that the nitrite accumulation is not induced by unstable operation. Previous work has demonstrated that nitrite accumulation induced by salt inhibition is a common phenomenon in freshwater wastewater treatment because AOB seems to be more resistant to elevated chloride concentrations compared to NOB (Chen et al. 2003). However, few researchers keep their eyes on halophilic nitritation. Antileo et al. (2002) demonstrated that taking marine sediments and industrial effluents as inoculation sources led to the production of nitrite as a dominant end-product of nitrification, while inocula from the animal manure resulted in complete conversion to nitrate. This means that inoculation source could be responsible for end-products of nitrification (nitrite or nitrate). According to the natural habitat investigation, high nitrite accumulations are observed in thin layers of sediment on continental shelves (Rysgaard et al. 2004). Thus, it is reasonable to refer that nitritation in this study is possibly related to the microorganism population in estuarine sediments.

\section{Kinetics characterization}

Establishing kinetic parameters for nitrification and denitrification is an important issue for the design and operation
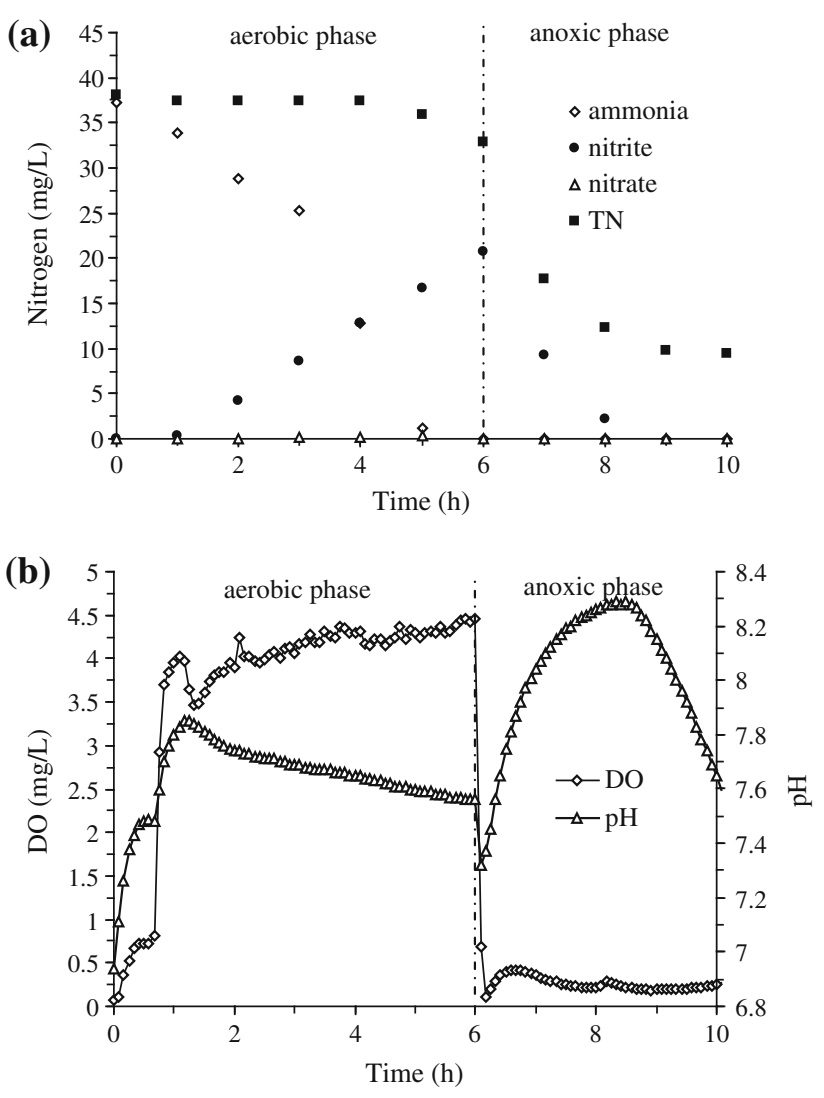

Fig. 2 DO and $\mathrm{pH}$ evolution with dynamics of nitrogen in one typical cycle: a nitrogen dynamics and $\mathbf{b} \mathrm{DO}$ and $\mathrm{pH}$ profile

of wastewater treatment plants. Till now, there are no kinetic parameters available for bio-treatment of hypersaline wastewater by halophiles. In order to evaluate the effects of initial ammonia or nitrite concentration on degradation rate, ammonia and nitrite consumption on different initial concentrations are plotted in Fig. 3. Such plots were used for the determination of specific growth rates at various initial ammonia and nitrite concentrations. Linear fitting with high coefficient correlations is obtained (Fig. 3a), which indicates that the ammonia degradation is the zero order reaction in the tested region. The zero order reaction is also found in the freshwater counterpart due to the small half saturation coefficient of AOB. Denitrifying nitrite was found to follow pseudo-second order reaction (Fig. 3b). This is different from the case of non-halophilic denitrifying bacteria, which can be better modeled as a first order function of nitrite concentration (Peyton et al. 2001).

The kinetic constants obtained by the experiments and modeling described in "Materials and methods" are summarized in Table 2. Comparing the kinetic parameters with those published in literatures, it is evident that halophilic AOB has a lower $\mu_{\mathrm{A}}$ but higher $q_{\mathrm{NH}_{4}^{+}-\mathrm{N}}$ than freshwater AOB. The slow $\mu_{\mathrm{A}}$ can result in long cultivation time and the difficulty of sustaining sufficient biomass in biological 

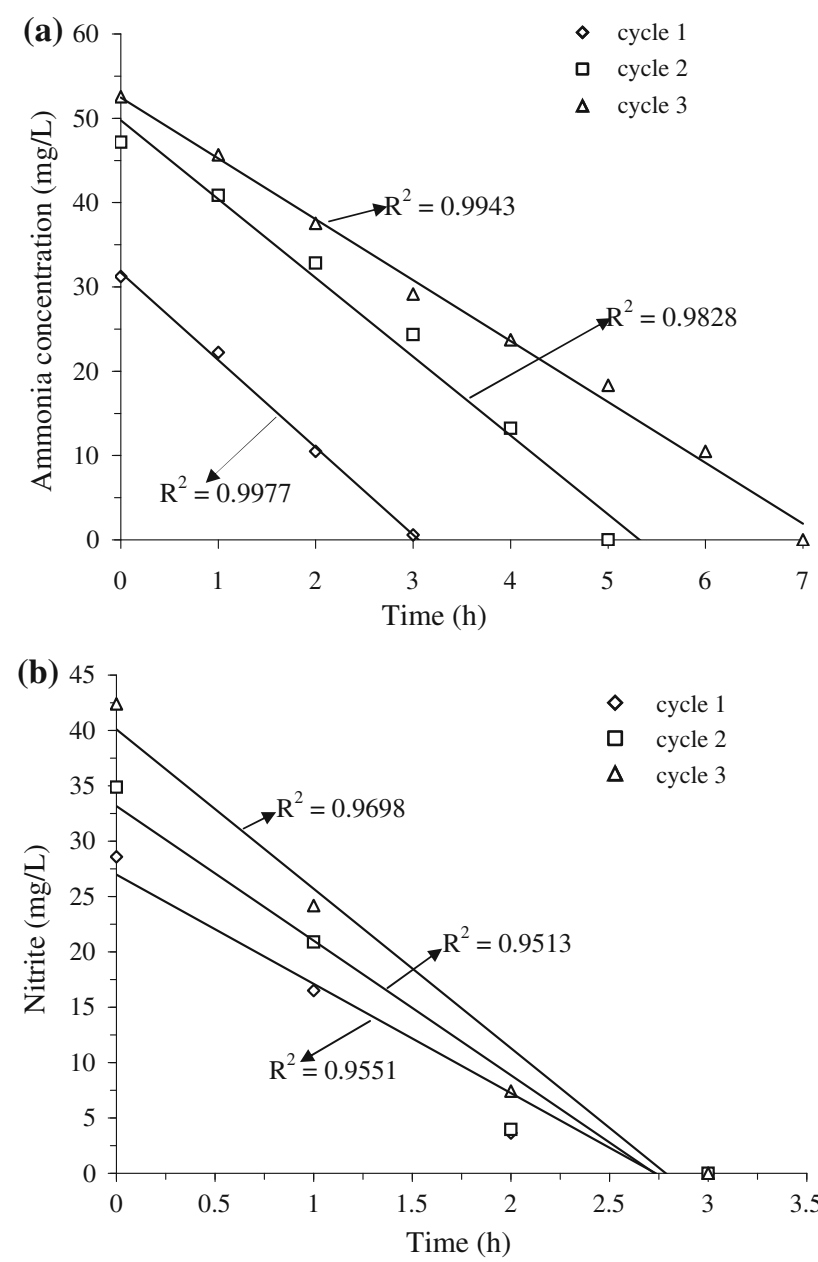

Fig. 3 Track study of ammonia oxidation and nitrite reduction in SBR at different loadings: a ammonia oxidization and $\mathbf{b}$ nitrite reduction. $K$ means slope

system. A possible solution to reduce the cultivation time is by inoculating highly enriched halophiles, which is highly dependent on the inocula source. To sustain these slowgrowth halophiles in biological system, long sludge retention time (SRT) was required. Therefore, the fixed growth process was recommended because it has advantage to sustain slow-growth bacteria. Some successful practice also proved that engineering halophilic or halotolerant bacteria by attaching them on some media facilitated the maintenance of high halophilic biomass (Abou-Elela et al. 2010; Sudarno et al. 2010). Figure 4a shows the comparison of halophilic $q_{\mathrm{NH}_{4}^{+}-\mathrm{N}}$ with that obtained by Uygur (2006) in varying salinities, clearly indicating that halophilic $q_{\mathrm{NH}_{4}^{+}-\mathrm{N}}$ is higher than the value of both freshwater $\mathrm{AOB}$ and salt-acclimated freshwater $\mathrm{AOB}$ in saline conditions. Obvious salt dependence is observed in the range of $0-120 \mathrm{~g} / \mathrm{L}$ salinity, indicating that the AOB mostly is salt obligated. As salinity increased in the wastewater,
Table 2 Overview of kinetic parameters obtained in some study

\begin{tabular}{|c|c|c|c|}
\hline$\mu_{\mathrm{A}}\left(\mathrm{h}^{-1}\right)$ & $\begin{array}{l}q_{\mathrm{NH}_{4}^{+}-\mathrm{N}} \\
{[\mathrm{mg} \mathrm{N} /} \\
\text { (g VSS h)] }\end{array}$ & $\begin{array}{l}q_{\mathrm{NO}_{2}^{-}-\mathrm{N}} \\
{[\mathrm{mg} \mathrm{N} /} \\
(\mathrm{g} \text { VSS h)] }\end{array}$ & Reference \\
\hline $\begin{array}{l}0.0108 \\
\quad(30 \mathrm{~g} / \mathrm{L})^{\mathrm{a}}\end{array}$ & $\begin{array}{l}3.8243 \\
\quad(30 \mathrm{~g} / \mathrm{L})^{\mathrm{a}}\end{array}$ & $\begin{array}{l}3.0202 \\
\quad(30 \mathrm{~g} / \mathrm{L})^{\mathrm{a}}\end{array}$ & This study \\
\hline $\begin{array}{l}0.0193 \\
\quad(\text { freshwater })^{\mathrm{a}}\end{array}$ & No data & $\begin{array}{l}27.5 \\
\quad(\text { freshwater })^{\mathrm{a}}\end{array}$ & Gao et al. (2010) \\
\hline $\begin{array}{l}0.0504 \\
\quad(\text { freshwater })^{\mathrm{a}}\end{array}$ & No data & No data & $\begin{array}{l}\text { Jubany et al. } \\
\text { (2008) }\end{array}$ \\
\hline $\begin{array}{l}0.0420 \\
\quad(\text { freshwater })^{\mathrm{a}}\end{array}$ & No data & No data & $\begin{array}{l}\text { Gujer et al. } \\
\text { (1999) }\end{array}$ \\
\hline No data & $\begin{array}{l}3.04 \\
\quad(\text { freshwater })^{\mathrm{a}}\end{array}$ & No data & Uygur (2006) \\
\hline No data & $1.45(60 \mathrm{~g} / \mathrm{L})^{\mathrm{a}}$ & No data & Uygur (2006) \\
\hline No data & $\begin{array}{l}4.76 \\
(\text { freshwater })^{\mathrm{a}}\end{array}$ & No data & $\begin{array}{c}\text { Panswad and } \\
\text { Anan (1999) }\end{array}$ \\
\hline No data & $2.14(30 \mathrm{~g} / \mathrm{L})^{\mathrm{a}}$ & No data & $\begin{array}{l}\text { Panswad and } \\
\text { Anan (1999) }\end{array}$ \\
\hline No data & No data & $12.5(50 \mathrm{~g} / \mathrm{L})^{\mathrm{a}}$ & Soto et al. (2007) \\
\hline No data & No data & $12.7(24 \mathrm{~g} / \mathrm{L})^{\mathrm{a}}$ & $\begin{array}{l}\text { Glass and } \\
\text { Silverstein } \\
\text { (1999) }\end{array}$ \\
\hline
\end{tabular}

a The salinity

$q_{\mathrm{NH}_{4}^{+}-\mathrm{N}}$ of the salt-acclimated and freshwater biological system decreased. However, maximum halophilic $q_{\mathrm{NH}_{4}^{+}-\mathrm{N}}$ was found at $40 \mathrm{~g} / \mathrm{L}$ salinity in this study. Therefore, the advantage of using halophiles to treat saline wastewater is more significant when high salinity is applied.

Rate of denitrifying nitrite by halophilic denitrifiers is slow compared with freshwater and salt-acclimated systems. Table 2 lists $q_{\mathrm{NO}_{2}^{-}-\mathrm{N}}$ obtained in this study and other research, showing that denitrifying rate of freshwater bacteria is eightfold more than that of halophilic system. Even in hypersaline conditions, denitrifying rate of freshwater bacteria is still 3- to 4-fold more than that of halophilic system. Further experiments investigate salt effect on halophilic $q_{\mathrm{NO}_{2}^{-}-\mathrm{N}}$ (Fig. 4 b), showing that optimal salinity is $20-50 \mathrm{~g} / \mathrm{L}$. The slow denitrifying rate by halophilic system is possibly owing to the type of denitrification carbon source. Carbon source has been established to affect the halophilic or halotolerant denitrifying rates in some research. Peyton et al. (2001) reported that denitrification by moderate halophiles, Halomonas campisalis, was highly dependent on the carbon source. The specific nitrate reduction rate coefficient of $H$. campisalis was highest when amending with acetate, while no nitrate reduction was observed when ethanol or methanol was provided as an electron donor. Therefore, a further research on denitrification carbon source will contribute to explain the slow nitrite reduction rate in the halophilic system. 

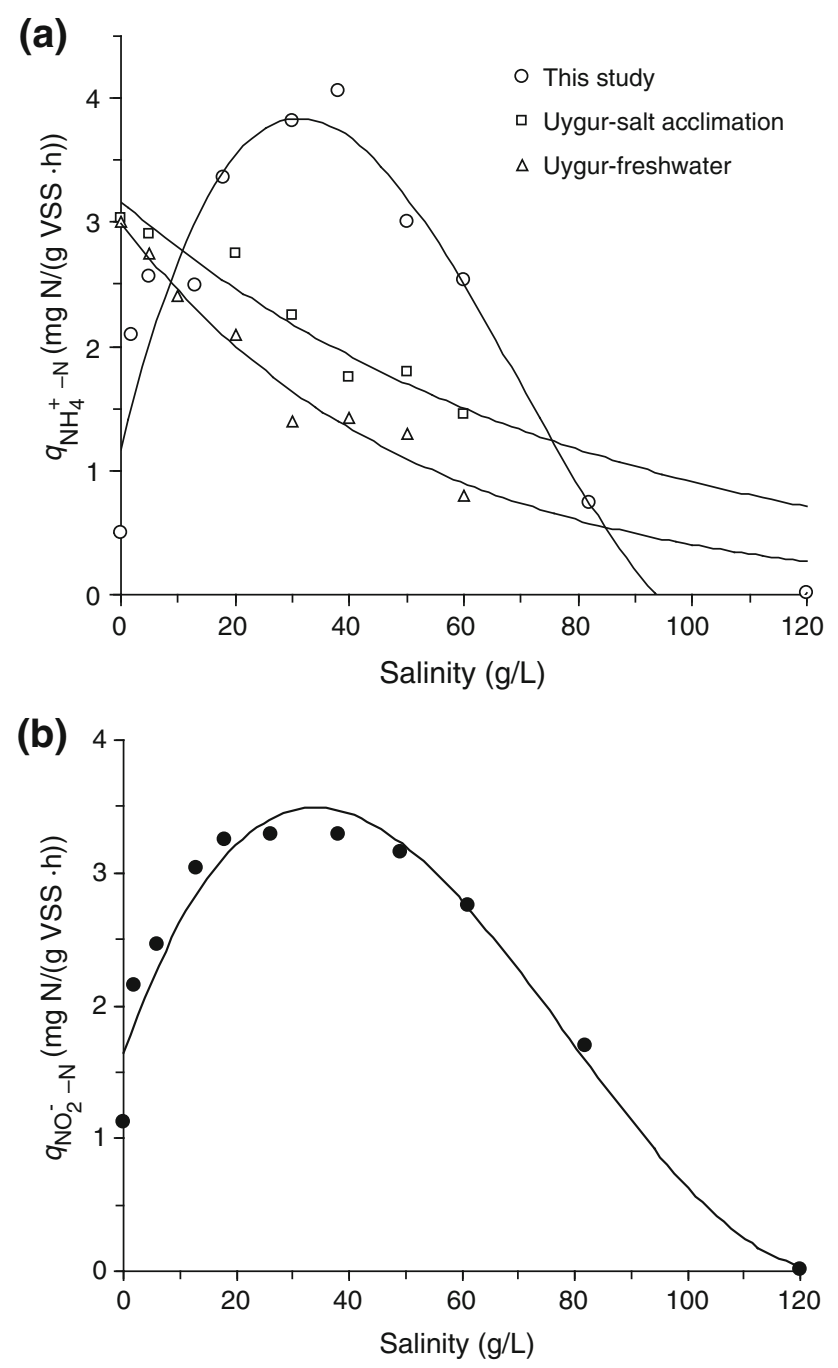

Fig. 4 Variation of specific ammonia and nitrite removal rate with salinities: a comparison of specific ammonia removal rates with results from Uygur (2006) and b the specific nitrite removal rates

Sludge flocs and settleability

Biosolid-liquid separation by gravity settling is one of the most critical operations in the activated sludge process. The effective solid-liquid separation depends on the formation of dense flocs and the good settling of activated sludge. During the whole operation, biomass concentration (MLSS and VSS), SVI and SV\% were measured, which were shown in Fig. 5. The low ratio of VSS to MLSS (3\%) on the first day indicates that the original inoculum is mainly composed of inorganic matters (shown in Fig. 5b). Although VSS concentration increased gradually as the increase of operation days (shown in Fig. 5a), the low ratio of VSS to MLSS was kept during phases A and B due to the high inorganic content in sludge. High inorganic content in sludge limited the effective oxygen transfer and thus consumed more aeration energy. Considering the negative
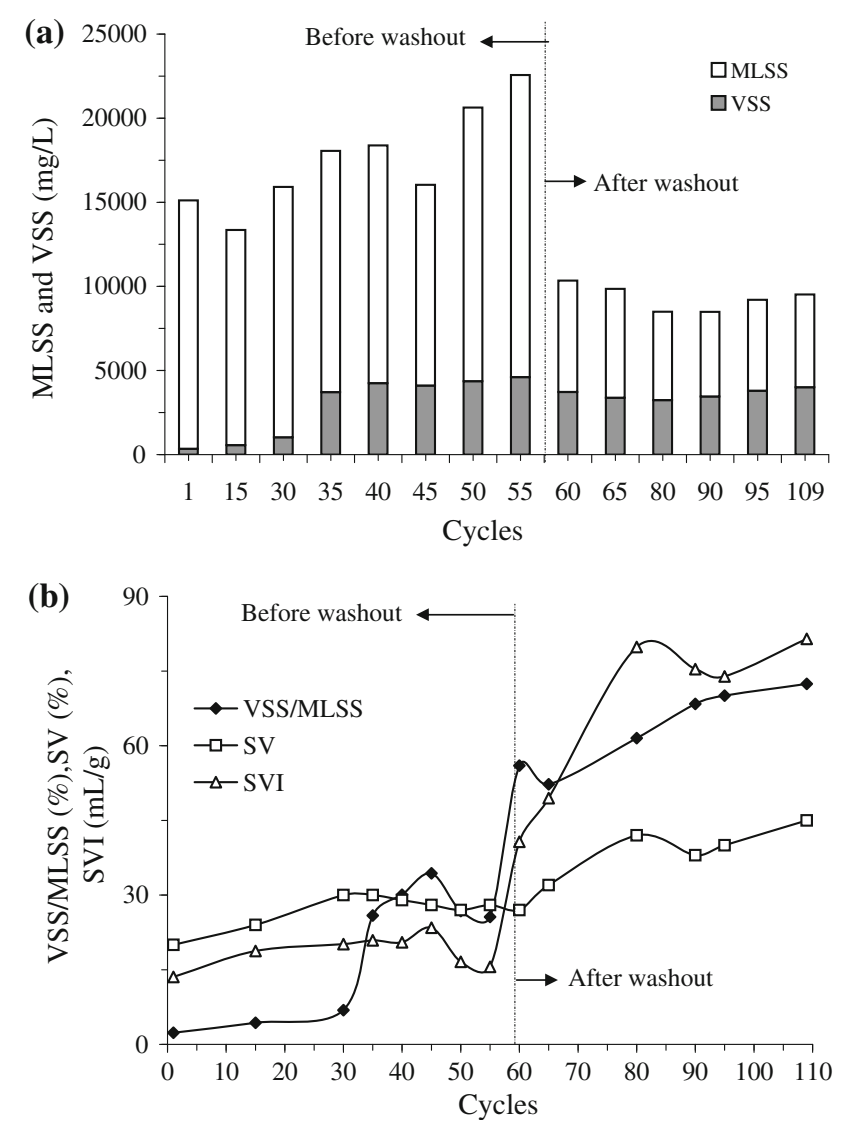

Fig. 5 Profiles of activated sludge prosperity during operations: a time course profile of activated sludge concentration and $\mathbf{b}$ time course profile of activated sludge prosperity

effect of high inorganic matters, washout of inorganic matters from sludge was carried out at the end of phase B. After washout, the ratio of VSS to MLSS increased to about $60 \%$, which is similar to the value of the freshwater activated sludge in municipal wastewater treatment plants (WWTPs). High ratio of VSS to MLSS was maintained during phases $\mathrm{C}$ and $\mathrm{D}$.

SEM examination allows us to find that estuarine sediments are made up of the anomalous inorganic platelets (Fig. 6a). Very occasionally, separate bacterium can be found on these platelets. After 58-day operation, bacterial proliferation can be observed in Fig. 6b. The filamentous bacteria prevail around the inorganic platelets and bacterial cluster attached on inorganic components. It can be concluded that bacterial attachment growth on inorganic platelets was the main character of floc aggregation before washout inorganic matters from sludge. After sand washout, sludge sample was taken for microscopic examination at day 120. The image showed that flocculated sludge was densely packed with microbial colonies (Fig. 6c). Inorganic platelets can rarely be found. The phenomena that salt in wastewater reduced the abundance of filamentous 
Fig. 6 SEM pictures: a estuarine sediments as the inocula, $\mathbf{b}$ activated sludge sampled at day 58. c, d activated sludge sampled at day 120 with 1 and $5 \mathrm{~K}$ amplification, respectively
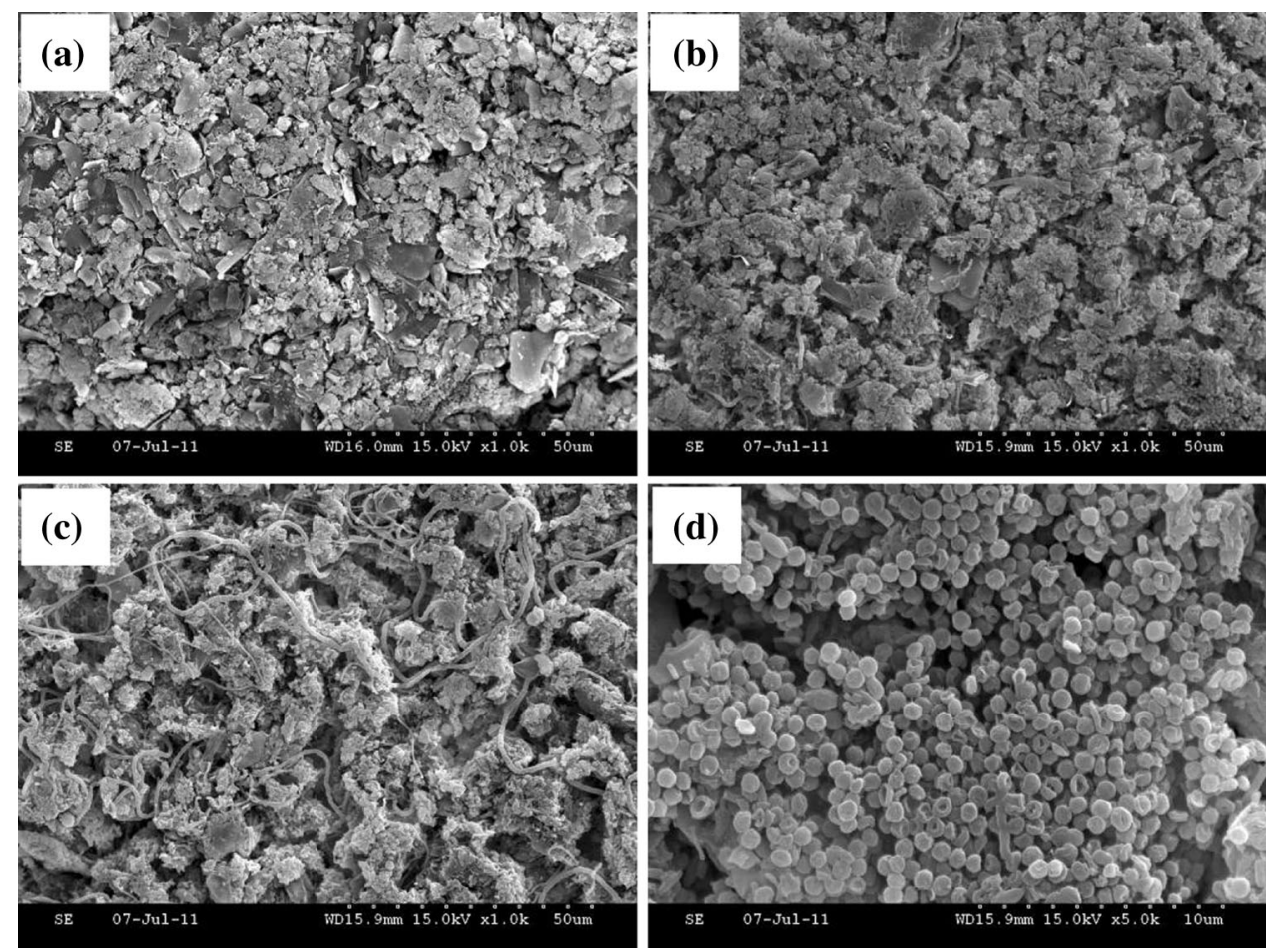

organisms were observed by many researchers (Kargi and Dincer 1996; Panswad and Anan 1999). However, filamentous bacteria were not inhibited by salinity in this study. The floc matrix was characterized by a net-like structure embedded by filamentous bacteria. Figure 6d shows amplified versions of the images, indicating that coccus and short-rod bacteria are the predominant microbial morphology. During the operation, floc size of activated sludge was found to increase as the biomass concentration increased. The mean size of the sludge flocs was $71 \mu \mathrm{m}$ varying between 32 and $120 \mu \mathrm{m}$ at day 58. After sand washout, the mean floc size of activated sludge increased to $105 \mu \mathrm{m}$ (varying from 38 to $194 \mu \mathrm{m}$ ) at day 120 , which is still much smaller than that of the freshwater activated sludge in WWTPs (mean size of $150 \mu \mathrm{m}$ ) (Jin et al. 2003). In general, flocs with small size and net-like structure lead to poor flocculation properties. However, good settling and flocculation property was observed during the operation. During phases A and B, sludge has a SV\% of lower than $30 \%$ and SVI of lower than $20 \mathrm{~mL} / \mathrm{g}$ (Fig. 5b). Improved settling and compaction properties of sludge can be established with SVI of $80 \mathrm{~mL} / \mathrm{g}$ and SV\% of $40 \%$ during phase D (Fig. 5b). The situation is not in line with the case of saline wastewater treatment. Many researchers report that elevated salt levels have a negative impact on the settling characteristics of freshwater activated sludge and result in reduction of settling efficiency (Kargi and Dincer 1996; Panswad and Anan 1999). Comparing this result with acclimated freshwater activated sludge, it is reasonable to conclude that halophilic filamentous bacteria may be responsible for good settling and flocculation. Filamentous bacteria provide the framework of bacterial aggregation, which ensures effective solid-liquid separation and overcome settleability difficulties of the acclimated freshwater sludge in hypersaline environment.

\section{Population of nitrifiers}

The estuary is a special habitat characterized by steep physical-chemical gradients of salinity, nitrogen, $\mathrm{pH}$, oxygen and organic loading, which regulate the diversity, distribution, and activity of nitrifiers (Bernhard and Bollmann 2010). After estuarine sediments were transferred into the wastewater treatment bioreactor, an important academic question is whether the significant difference between environmental conditions of the natural habitat and that of the reactor would trigger the shift of nitrifier community. Until recently, our understanding of the aerobic ammonia oxidizers may be classified into two categories: domain archaea and domain bacteria. Figure 7 shows the abundance of ammonia-oxidizing archaea (AOA) and AOB in original estuarine sediments and in the activated sludge. Archaeal amoA genes abundance in estuaries is $10^{5}$ gene copies per gram of sediment, which is in accordance with the results $\left(10^{4}-10^{9}\right.$ gene copies per gram of sediment) obtained by previous investigation (Mosier and Francis 2008; Santoro et al. 2008). Bacterial amoA genes abundance in estuaries is $10^{6}$ gene copies per gram of 


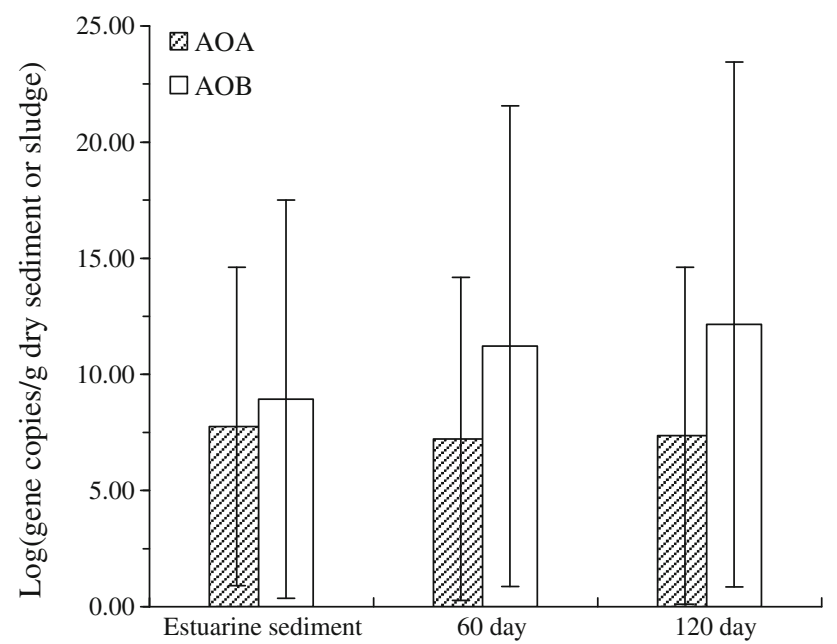

Fig. 7 The relevant archaeal and bacterial amoA gene copy numbers in estuarine sediments, the activated sampling at day 60 and 120 . Error bars indicate standard deviation $(n=3)$

sediment, which is also consistent with reports, ranging from $10^{4}$ to $10^{8}$ copies per gram of sediment (Mosier and Francis 2008; Santoro et al. 2008). AOB abundance outnumbers AOA by one order of magnitude, suggesting that $\mathrm{AOB}$ community is likely to be the predominant nitrifiers in the sediments. The ratio of $\mathrm{AOB}$ to AOA was further augmented to $10^{3}$ after 120-day operation, which indicated the conditions in reactor favor the growth of $\mathrm{AOB}$ rather than AOA. Unlike that AOA outnumbers AOB in most studies, the abundance investigation in estuarine sediments and in the bioreactor proved the dominance of AOB. Thus, the further investigation of nitrifier community only focused on AOB. According to reports that gammaproteobacterial AOB were apparently lacked in estuaries (Ward et al. 2007), only betaproteobacterial AOB were investigated in this study. Table 3 shows the results of the double probe examinations with NSO190/EUB ${ }_{\text {mix }}$, NEU/NSO190 and NSMR76/EUB ${ }_{\text {mix }}$ in the estuarine sediments and in the activated sludge. AOB accounted for only a small portion of entire microbial population in the natural sediments. Almost all the NSO190-stained cells could be visualized by the NEU probe by the picture of NEU/NSO190 examinations, while no hybridization signals of NSMR76/EUB ${ }_{\text {mix }}$ were observed. Thus, it can be anticipated that AOB cluster mainly is a halophilic and halotolerant member of the genus Nitrosomonas rather than Nitrosomonas marina-like AOB. The NOB occurring in natural sediments was examined by employing probes of NIT3/EUB $\mathrm{Emix}_{\text {ax }}$ and NTSPA685/EUB mix $_{\text {. No hybridization signals were }}$ obtained in the results, implying the possible absence of NOB in the estuarine sediments. According to the report, betaproteobacterial AOB communities were regulated by the salinity in estuary, with communities at the freshwater
Table 3 Nitrifier population visualized by FISH

\begin{tabular}{|c|c|c|c|}
\hline Nitrifiers population & $\begin{array}{l}\text { Probes } \\
\text { of FISH }\end{array}$ & $\begin{array}{l}\text { Estuarine } \\
\text { sediments }\end{array}$ & $\begin{array}{l}\text { Activated } \\
\text { sludge } \\
\text { sampled a } \\
120 \text { day }\end{array}$ \\
\hline $\begin{array}{l}\text { Ammonia oxidizers of } \\
\beta \text {-proteobacteria }\end{array}$ & $\begin{array}{l}\text { NSO190/ } \\
\text { EUB }_{\text {mix }}\end{array}$ & + & +++ \\
\hline $\begin{array}{l}\text { Halophilic and halotolerant } \\
\text { Nitrosomonas sp. }\end{array}$ & $\begin{array}{l}\text { NEU/ } \\
\text { NSO190 }\end{array}$ & + & +++ \\
\hline $\begin{array}{l}\text { Nitrosomonas marina-like } \\
\text { AOB }\end{array}$ & $\begin{array}{l}\mathrm{NSMR76/} \\
\text { EUB }_{\text {mix }}\end{array}$ & - & - \\
\hline \multicolumn{4}{|l|}{ Nitrite oxidizers } \\
\hline Nitrobacter sp. & $\begin{array}{l}\text { NIT3/ } \\
\text { EUB }_{\text {mix }}\end{array}$ & - & - \\
\hline $\begin{array}{l}\text { Nitrospira mascoviensis, } \\
\text { Nitrospira marina, } \\
\text { aquarium clone } 710-9\end{array}$ & $\begin{array}{l}\text { NTSPA685/ } \\
\text { EUB }_{\text {mix }}\end{array}$ & - & + \\
\hline
\end{tabular}

- not detected, + present, +++ abundant

end composed of sequences related to both the Nitrosomonas and Nitrosospira genera, while communities at the marine end of the gradient tend to be dominated by Nitrosospira-like sequences (Bernhard and Bollmann 2010). So, the dominance of genus of Nitrosomonas in our research is not surprising. However, the reason for the NOB absence remains unclear. In order to monitor the nitrifier community shift, the same combined double hybridization technology was applied to activated sludge sampled at day of 120 . A significant increase of AOB percentage to all bacteria was found by employing the NSO190/EUB ${ }_{\text {mix }}$ examinations, which could explain the high nitrification activity found in process treatment. NEU/NSO190 examinations indicated that halophilic and halotolerant members of the genus Nitrosomonas are the dominant AOB in activated sludge. This conclusion is further confirmed by results of NSMR76/ EUB $_{\text {mix }}$ hybridization. Salt dependence of biomass and the optimal salinity of $40 \mathrm{~g} / \mathrm{L}$ can be found in Fig. 4, which allowed us to predict that AOB biomass was mainly composed of halophilic Nitrosomonas. Combining the microbial morphology observation (Fig. 6), it can be deduced that the halophilic AOB is mainly composed of Nitrosococcus mobilis and Nitrosomonas europaea. Although still no obvious hybridization signals are found in activated sludge using double probe of NIT3/EUB ${ }_{\text {mix }}$, NTSPA685/EUB ${ }_{\text {mix }}$ examination presents a very small portion in hybridization. The result indicates that NOB possibly contains $N$. moscoviensis, N. marina, aquarium clone 710-9. Linking the results of molecular biology with the process performance may explain the high NAR during all experiments. However, the question that what process conditions limit the growth of NOB in the bioreactor is left for future research. 


\section{Conclusion}

This study demonstrates a successful start-up of halophilic biological nitrogen removal system processing hypersaline sewage by inoculating estuarine sediments. The SBR process was operated continuously for 140 days and the stable nitrogen removal via nitrite was achieved after 30-day operation. The mixed nitrifier system is dominated by halophilic Nitrosomonas obligated with optimal salt requirement of $40 \mathrm{~g} / \mathrm{L}$ salinity. The population size of AOB overwhelming AOA is independent of the significant niche difference in natural habitat and wastewater treatment reactor. During the operation, high nitrite accumulation was found as the noted phenomena regardless of specific ammonia loadings. The finding is related to the overwhelming growth of AOB than NOB in nitrification community. The reason for the absence of halophilic NOB is left for further research. Good settling and flocculation prosperity is observed, providing effective biosolid-liquid separation. The halophilic AOB are established to possess higher specific nitrifying rate and lower specific growth rate than those of the freshwater counterparts. A significant low denitrification rate is also found possibly due to the applied carbon source. This study suggests the possibility of application of estuarine sediment consortia for efficient nitrogen removal from hypersaline wastewater. Such an application would overcome limitations and difficulties in applying acclimation of freshwater bacteria for hypersaline wastewater treatment.

Acknowledgments This research is supported by the National Natural Science Foundation of China (Project No. 50908002 and No. 51178004), the Natural Science Foundation of Beijing (No. 8102006), and Beijing education committee project (Project No. KM201210005007). Dr. Guibing Zhu and Dr. Shanyun Wang are gratefully acknowledged for kind help in bacterial abundance analysis.

\section{References}

Abou-Elela SI, Kamel MM, Fawzy ME (2010) Biological treatment of saline wastewater using a salt-tolerant microorganism. Desalination 250(1):1-5

Amann RI, Krumhol ZL, Stahl DA (1990) Fluorescent-oligonucleotide probing of whole cells for determinative, phylogenetic, and environmental-studies in microbiology. J Bacteriol 172(2):762-770

Antileo C, Aspe E, Urrutia H, Zaror C, Roeckel M (2002) Nitrifying biomass acclimation to high ammonia concentration. J Environ Eng 128(4):367-375

APHA (1995) Standard methods for the examination of water and wastewater, 21st edn. American Public Health Association, Washington (2-58-59, 4-103-125, 5-13-17)

Bassin J, Dezotti M, Sant'Anna GL Jr (2011) Nitrification of industrial and domestic saline wastewaters in moving bed biofilm reactor and sequencing batch reactor. J Hazard Mater 185(1):242-248
Bernhard AE, Bollmann A (2010) Estuarine nitrifiers: new players, patterns and processes. Estuar Coast Shelf S 88(1):1-11

Burrell PC, Phalen CM, Hovanec TA (2001) Identification of bacteria responsible for ammonia oxidation in freshwater aquaria. Appl Environ Microb 67(12):5791-5800

Chen G, Wong M, Okabe S, Watanabe Y (2003) Dynamic response of nitrifying activated sludge batch culture to increased chloride concentration. Water Res 37(13):3125-3135

Cui YW, Peng CY, Peng YZ, Ye L (2009) Effects of salt on microbial populations and treatment performance in purifying saline sewage using the MUCT process. Clean 37(8):649-656

Gao DW, Peng YZ, Wu WM (2010) Kinetic model for biological nitrogen removal using shortcut nitrification-denitrification process in sequencing batch reactor. Environ Sci Technol 44(13): 5015-5021

Gharsallah N, Khannous L, Souissi N, Nasri M (2002) Biological treatment of saline wastewaters from marine-products processing factories by a fixed-bed reactor. J Chem Technol Biotechnol 77 (8):865-870

Glass C, Silverstein J (1999) Denitrification of high-nitrate, highsalinity wastewater. Water Res 33(1):223-229

Gross A, Nemirovsky A, Zilberg D, Khaimov A, Brenner A, Snir E, Ronen Z, Nejidat A (2003) Soil nitrifying enrichments as biofilter starters in intensive recirculating saline water aquaculture. Aquaculture 223(1-4):51-62

Gujer W, Henze M, Mino T, van Loosdrecht M (1999) Activated sludge model no. 3. Water Sci Technol 39(1):183-193

Hovanec TA, Taylor LT, Blakis A, Delong EF (1998) Nitrospira-like bacteria associated with nitrite oxidation in freshwater aquaria. Appl Environ Microbiol 64(1):258-264

Jin B, Wilén B, Lant P (2003) A comprehensive insight into floc characteristics and their impact on compressibility and settleability of activated sludge. Chem Eng J 95(1-3):221-234

Jubany I, Carrera J, Lafuente J, Baeza JA (2008) Start-up of a nitrification system with automatic control to treat highly concentrated ammonium wastewater: experimental results and modeling. Chem Eng J 144(3):407-419

Kargi F, Dincer AR (1996) Effect of salt concentration on biological treatment of saline wastewater by fed-batch operation. Enzym Microb Technol 19(7):529-537

Lefebvre O (2006) Treatment of organic pollution in industrial saline wastewater: a literature review. Water Res 40(20):3671-3682

Mobarry BK, Wagner M, Urbain V, Rittmann BE, Stahl DA (1996) Phylogenetic probes for analyzing abundance and spatial organization of nitrifying bacteria. Appl Environ Microbiol 62(6):2156-2162

Mosier AC, Francis CA (2008) Relative abundance and diversity of ammonia-oxidizing archaea and bacteria in the San Francisco Bay estuary. Environ Microbiol 10(11):3002-3016

Panswad T, Anan C (1999) Impact of high chloride wastewater on an anaerobic/anoxic/aerobic process with and without inoculation of chloride acclimated seeds. Water Res 33(5):1165-1172

Peng YZ, Zhu GB (2006) Biological nitrogen removal with nitrification and denitrification via nitrite pathway. Appl Microbiol Biotechnol 73(1):15-26

Peyton BM, Mormile MR, Petersen JN (2001) Nitrate reduction with Halomonas campisalis: kinetics of denitrification at $\mathrm{pH} 9$ and $12.5 \% \mathrm{NaCl}$. Water Res 35(17):4237-4242

Rysgaard S, Glud RN, Risgaard-Petersen N, Dalsgaard T (2004) Denitrification and anammox activity in Arctic marine sediments. Limnol Oceanogr 49(5):1493-1502

Santoro AE, Francis CA, de Sieyes NR, Boehm AB (2008) Shifts in the relative abundance of ammonia-oxidizing bacteria and archaea across physicochemical gradients in a subterranean estuary. Environ Microbiol 10(4):1068-1079 
Soto O, Asp E, Roeckel M (2007) Kinetics of cross-inhibited denitrification of a high load wastewater. Enzym Microb Technol 40(6):1627-1634

Sudarno U, Bathe S, Winter J, Gallert C (2010) Nitrification in fixedbed reactors treating saline wastewater. Appl Microbiol Biotechnol 85(6):2017-2030

Uygur A (2006) Specific nutrient removal rates in saline wastewater treatment using sequencing batch reactor. Process Biochem 41(1):61-66

Wagner M, Rath G, Amann R, Koops HP, Schleifer KH (1995) In-situ identification of ammonia-oxidizing bacteria. Syst Appl Microbiol 18(2):251-264

Wang SY, Wang Y, Feng XJ, Zhai LM, Zhu GB (2011) Quantitative analyses of ammonia-oxidizing archaea and bacteria in the sediments of four nitrogen-rich wetlands in China. Appl Microbiol Biotechnol 90(2):779-787

Ward BB, Eveillard D, Kirshtein JD, Nelson JD, Voytek MA, Jackson GA (2007) Ammonia-oxidizing bacterial community composition in estuarine and oceanic environments assessed using a functional gene microarray. Environ Microbiol 9(10):2522-2538

Woolard CR, Irvine RL (1995) Treatment of hypersaline wastewater in the sequencing batch reactor. Water Res 29(4):1159-1168

Zhang Y, Arends JBA, Van de Wiele T, Boon N (2011) Bioreactor technology in marine microbiology: from design to future application. Biotechnol Adv 29(3):312-321

Zhuang X, Han Z, Bai Z, Zhuang G, Shim H (2010) Progress in decontamination by halophilic microorganisms in saline wastewater and soil. Environ Pollut 158(5):1119-1126 